\title{
HR PROFESSIONAL COMPETENCIES - A KEY TO HRM INTEGRATION WITH ORGANIZATIONAL OBJECTIVES
}

\section{RAJESHWARI G. M $^{1} \&$ S. MARIGOWDA ${ }^{2}$}

${ }^{1}$ Assistant Professor, PG Department of Commerce, Vidyavardhaka First Grade College, Mysuru, India

${ }^{2}$ Professor \& Head, PG Department of Commerce, Vidyavardhaka First Grade College, Mysuru, India

\section{ABSTRACT}

In a world of increasing revolution, complexity and competitiveness, there has never been a greater need to help HR professionals identify what it means to contribute more fully, effectively and insightfully. In this backdrop, the study is vital to HR Professionals as it empirically elicits what means to be an effective HR Professional. The study has been done with the main objective of evaluating the perception of HR Professionals about the HR Competencies which would play a paramount rolein the process of HRM integration with organizational objectives. The study also focuses its attention to determine how different HR Competencies influence the organizational outcomes. The sample size of 30 HR Professionals were chosen from both manufacturing and service sector from Bengaluru and Mysuru.The data was collected through well-structured questionnaire.Data has been analyzed by using statistical tools namely Excel and SPSS. Reliability of the questionnaire has been tested by using Cronbach alpha which arrived at the value of0.903.Significant influenceof HR Competencies on HRM integration with organizational objectives has been evidenced from the study with the help of Regression analysis.

KEY WORDS: Strategic Thinking, Business Knowledge, Credible Activist and Strategic Business Partner

Received: Jul 11, 2017; Accepted: Jul 26, 2017; Published: Jul 29, 2017; Paper Id.: IJHRMRAUG20173

\section{INTRODUCTION}

Today, the business world faces enormous change and HR professionals must do more than manage employee terms and conditions. As the bar has been elevated on HR, some lament that HR professionals cannot meet these higher expectations, and HR should be discounted or downsized and its functions automated or outsourced. Instead of denigrating HR, upgradation of HR professionals and HR departments need to be done to meet the challenges that confront contemporary organizations. For HR professionals to respond to changing business conditions, they must demonstrate new competencies. HR professionals who would have been successful in previous decades would not be effective today unless they are possessedwith new set of skills and competencies.

As per the opinion of van der Klink and Boon (2002), competence profiling provides a systematic and empirically certifiable set and narrative of competencies that are essential to carry out actions in a specific professional cluster, organization or profession. One of the earliest researcher,Boyatzis (1982) has identified four groups of HR managers' competencies such as the use of social power, a positive outlook, managing group processes and accurate self-assessment. Other scholars (Boselie and Paauve, 2005; Gorsline et al., 1998; McDaniel, 1998; Schuler et al., 2001; Sternberger, 2002) too added to list of competencies related to data analysis, problem solving and adaptability. 
HR managers' competencies have been divided into four groups as per the survey of 'World Personnel Managers Association' (Brewster et al., 2000) which are as follows:

- Competencies that form the individual style of operation

- $\quad$ Enterprise competencies

- Competencies needed for leadership, guidance and mentoring and

- Competencies which are necessary for the operational activities of HR managers.

The essential competencies of HR managers depend on the circumstance, locality, nature/size of organization and time frame within which they function. However, Ulrich et al. (2010) elicits HR managers' competencies as technical competencies, strategic thinking, business knowledge and creative problem solving. In all these sets of competencies, the question arises to what extent these are actual, rhetorical,kinder andambitious. Ulrich et.al., (2010) advocates that to be more professional, HR managers need to be credible activists who construct relationships of trust and have both a sustainable business and a strong HRM outlook. The HR Professional competencies that can contribute to the integration of HR activities with the organizational objectives can be categorized as follows (Ulrich et. al., 2010):

- Strategic Positioner: High performing HR professionals think and act from the outside/in. They are deeplyknowledgeable of and translate external business trends into internal decisions and actions. They understands the general business conditions (e.g. social, technological, economic, political, environmental and demographic trends) that affect their industry and geography. They also co-create their organizations' strategic responses to business conditions andcustomer expectations by helping frame and make strategic and organization choices.

- Credible Activist: Credibility comes when HR professionalsdo what they promise, build personal relationships of trust, and can be relied on to meetcommitments. Being a trusted advisor starts with deep business knowledge and acumen.As an activist, HR professionals have a point of view, not only about HR activities, but aboutbusiness demands. As activists, HR professionals learn how to influence others in a positive way through clear, consistent and high impact communications. To be credible activists, HR professionals need to be self-awareand committed to building their professionalism.

- Capability Builder: An effective HR professional melds individual abilities into an effective and strongorganization by helping to define and build critical organization capabilities. HR professionals should facilitate capability audits to determine the identity of organizations. HR professionals can help line managers create meaning so that the capability of the organization reflects the deeper values of the employees.

- Change Champ: As change champions, HR professionals ensure that organization actions are integrated and sustained through disciplined change processes. Strong HR professionals make an organization's internal capacity for change match or lead the external pace of change. As change champions, HR professionals help make change happen at institutional (changing patterns), initiative (making things happen), and individual (enabling personal change) levels.

- HR Innovator and Integrator: Effective HR professionals innovate and integrate HR practices into unified 
solutions that solve business problems. They must know the latest insights on key HR Practice. They must also be able to turn the unique HR Practice areas such as human capital, performance accountability, communication and organization design into integrated solutions, generally around an organization's leadership brand.

- Technology Proponent: In recent years, technology has changed the way HR people think and do their administrative and strategic work. HR professionals who understand technology will create improved organizational identity outside the company and improve social relationships inside the company. As technology exponents HR Professionals have to access, advocate, analyze and align technology for information, efficiency and relationships.

On the nut shell, if the HR Professionals possesses and incorporate HR competencies in their routine transactions, they would in turn contribute in the integration of HR activities with organizational objectives by becoming strategic business partners.

\section{SCOPE}

The study is focused on examining the perception of HR Professionals which include both HR Managers and HR Consultants of manufacturing and service sectors in Bengaluru and Mysurucities by covering 15 top corporates and 15 esteemed HR Consultancies respectively. The study is carried out to ascertain the role of HR competencies played in HRM integration with organizational objectives.

\section{OBJECTIVES}

The study was carried out with the objectives mentioned below

- To present conceptual framework relating to HR Professional competencies.

- To evaluate the perception of HR Professionals about HR Professional competencies.

- To ascertain the effect ofHR Competencies on HRM integration with organizational objectives.

\section{HYPOTHESIS}

$\mathbf{H}_{\mathbf{0}}$ :HR Professional Competencies have no significant influence on HRM integration with organizational objectives.

$\mathbf{H}_{1}$ :HR Professional Competencies have significant influence on HRM integration with organizational objectives.

\section{RESEARCH METHODOLOGY}

\section{Data Collection}

Data has been collected by primary source using structured questionnaire by testing its reliability.

\section{Sample Size}

The sample size taken for the study was 30 which includes both HR Managers and HR Consultants 15 each, from Manufacturing and service sectors. 


\section{Statistical Tools Applied}

Excel has been used to gather the data and SPSS has been used to analyze the data and for testing the reliability of questionnaire which stood in the value of 0.903 by using Cronbach alpha. SPSS also been used for evaluating the effect ofindependent variable on dependent variable with the help of Regression. Analysis and interpretation of data collected has been carried out by using charts and tables.

\section{DATA ANALYSIS AND INTERPRETATION}

Data analysis and interpretation is carried out in two stages. Demographic factors has been analyzed and interpreted in table 1, whereas table 2, 3 and 4 shows the results about the how HR Competencies influence HRM integration with organizational objectives.

Table 1: Demographic Profile

\begin{tabular}{|c|c|c|c|c|c|c|c|c|c|c|c|c|c|c|}
\hline \multicolumn{3}{|c|}{ Gender } & \multicolumn{3}{|c|}{ Age } & \multicolumn{3}{|c|}{ Education } & \multicolumn{3}{|c|}{ Designation } & \multicolumn{3}{|c|}{ Experience } \\
\hline & $\mathbf{F}$ & $\%$ & & F & $\%$ & & $\mathbf{F}$ & $\%$ & & $\mathbf{F}$ & $\%$ & & $\mathbf{F}$ & $\%$ \\
\hline Male & 17 & 56.7 & $\begin{array}{l}<25 \\
\text { Yrs }\end{array}$ & 6 & 20.0 & Graduation & 7 & 23.3 & $\begin{array}{c}\text { HR } \\
\text { Manager }\end{array}$ & 15 & 50.0 & $\begin{array}{l}1-5 \\
\text { Yrs }\end{array}$ & 11 & 36.7 \\
\hline Female & 13 & 43.3 & $\begin{array}{c}25-35 \\
\text { Yrs }\end{array}$ & 14 & 46.7 & $\begin{array}{c}\text { Post- } \\
\text { Graduation }\end{array}$ & 21 & 70.0 & $\begin{array}{c}\text { HR } \\
\text { Consultant }\end{array}$ & 15 & 50.0 & $\begin{array}{l}5-10 \\
\text { Yrs }\end{array}$ & 9 & 30.0 \\
\hline & & & $\begin{array}{c}36-45 \\
\text { Yrs }\end{array}$ & 9 & 30.0 & $\begin{array}{c}\text { Diploma in } \\
\text { HR } \\
\end{array}$ & 2 & 6.7 & & & & $\begin{array}{c}10-15 \\
\text { Yrs } \\
\end{array}$ & 6 & 20.0 \\
\hline & & & $\begin{array}{l}>56 \\
\text { Yrs }\end{array}$ & 1 & 3.3 & & & & & & & $\begin{array}{c}15-20 \\
\text { Yrs }\end{array}$ & 2 & 6.7 \\
\hline & & & & & & & & & & & & $\begin{array}{l}>20 \\
\text { Yrs }\end{array}$ & 2 & 6.7 \\
\hline
\end{tabular}

(Source: Primary)

The above table depicts that the majority of the respondents were male HR Professionals. Age-wise classification portrays that 14 respondents were in the age group of 25 to 35 years and with respect to education, 70 percent of them were post-graduates. The main stream of the respondents lie between the work experience of 1 to 15 years and very less percentage of them, have high experience.

\section{Hypothesis Testing}

Table 2: Model Summary

\begin{tabular}{|c|c|c|c|}
\hline Model & R & R Square & Adjusted R Square \\
\hline 1 & $0.858^{\mathrm{a}}$ & 0.723 & 0.720 \\
\hline
\end{tabular}

(Source: Primary)

Table 3: ANOVA

\begin{tabular}{|l|l|l|l|l|l|c|}
\hline \multicolumn{2}{|l|}{ Model } & Sum of Squares & \multicolumn{1}{c|}{ df } & Mean Square & F & Sig. \\
\hline \multirow{4}{*}{1} & Regression & 18.569 & 6 & 3.095 & 24.604 & $0.000^{\mathrm{a}}$ \\
\cline { 2 - 7 } & Residual & 24.277 & 193 & 0.126 & & \\
\cline { 2 - 7 } & Total & 42.846 & 199 & & & \\
\hline \multicolumn{2}{|l|}{ a. Predictors: (Constant), SP, CA, CB, CC, HRII, TP } & & & \\
\hline \multicolumn{2}{l}{ b. Dependent Variable: HRMI } & & & \\
\hline
\end{tabular}

(Source: Primary) 
Table 4: Coefficients ${ }^{\mathrm{a}}$

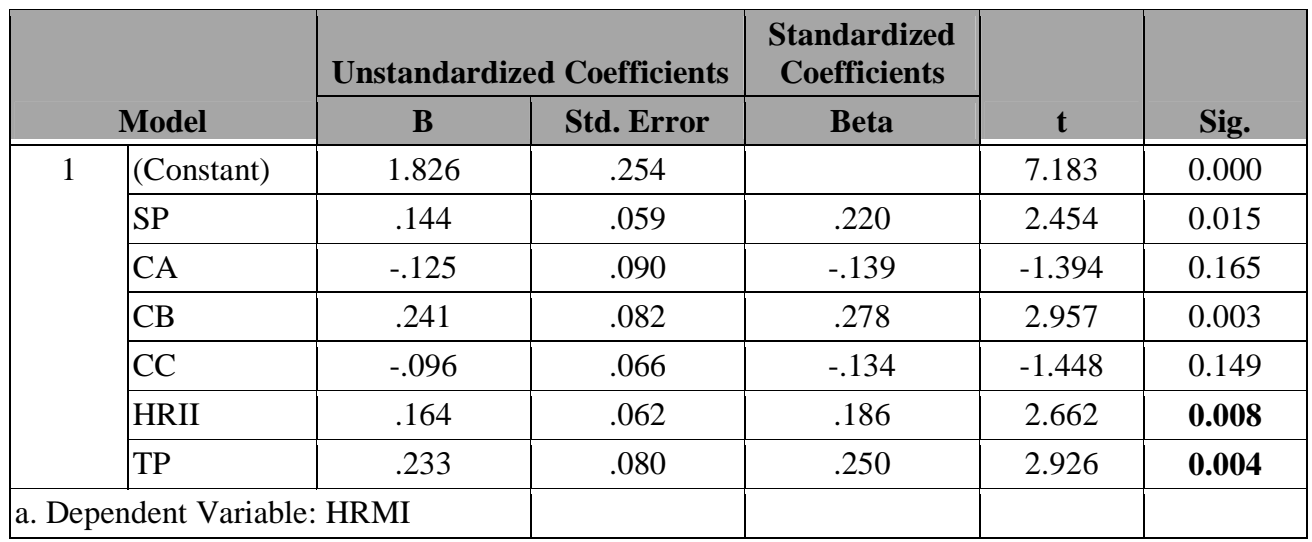

(Source: Primary)

Regression is used to explain the variation in one variable (dependent variable) based on variation in one or more other variables (called independent variables). The current study uses Linear Regression model to explain the variation in HR Professional competency scores with respect to Strategic Positioner (SP), Credible Activist (CA), Capability Builder (CB), Change Champ (CC), HR Innovator and Integrator (HRII) and Technology Proponent (TP).

Regression analysis was done to identify the significant HR Professional competency factors influencing the HRM integration with organizational objective. The results elicited that Credible Activist (with p value $0.165>0.05$ ) and Change Champ ( $\mathrm{p}$ value of $0.149>0.05$ ) competencies do not have a significant impact on HRM integration however, Strategic Positioner $(0.015<0.05)$, Capability Builder $(0.003<0.05)$, HR Innovator \& Integrator $(0.008<0.05)$ and Technology Proponent $(0.004<0.05)$ have a significant impact on the HRM integration with organizational objectives for both HR Managers and HR Consultants as there p values are less than 0.05 and significant at $5 \%$ level. The regression was a good fit, describing $72.3 \%$ of the variance in HRM Integration $\left(\mathrm{R}^{2}\right.$ adj $\left.=72 \%\right)$. HRM Integration was negatively related to the competencies of Credible Activist and Change Champ. However it was positively related to Strategic Positioner, Capability Builder, HR Innovator \& Integrator and Technology Proponent competencies.

Hence, from the above analysis it is evidenced that null hypothesis stating "HR Professional Competencies have no significant influence on HRM integration with organizational objectives" has been rejectedand alternative hypothesis is accepted.

\section{SUMMARY}

HR Professionals Competencies increase and differ in degree depending upon the phase of complexity, challenging circumstances and competitions. With increasing degrees of all the above factors the rate and differentiation of expected HR Professionals Competencies raise however, strategic thinking remains the key HR Professionals competency in the context of changing business trends. It is analyzed from the study that, with HR Professionals perception that HR Professional competencies have significant influence on HRM integration with organizational objectives.

Further, it is suggested that the HR Professionals

- Should update their skills and build confidence in order to place themselves at the table where key business decisions are taken. 
- Mustbuild their competencies to link HR programs and activities with outside the firm along with those inside the firm.

- Should not only concentrate on people needs but also must understand business needs and make business results happen.

- Along with their operational duties they must also plan and configure long term business strategies and integrate HR activities with those business strategies.

\section{CONCLUSIONS}

The context of the business obligated to succeed has upstretched the benchmark on HR Professionals. HR Professionals those who would have succeeded thirty, twenty, or even ten years ago would not be as likely to succeed today. HR Professionals are expected to perform new roles and to be able to exhibit those roles, they need new competencies. With the help of those competencies they can contribute and place themselves in accomplishment and achievement of business objectives.

\section{REFERENCES}

1. Boselie, P., \&Paauwe, J. (2005).Human resource function competencies in European companies. Personnel review, 34(5), 550-566.

2. Boyatzis, R. E. (1982). The competent manager: A model for effective performance. John Wiley \& Sons.

3. Brewster, C., Farndale, E., \& van Ommeren, J. (2000). HR competencies and professional standards. World Federation of Personnel Management Associations.

4. De Cieri, H., Fenwick, M., \& Hutchings, K. (2005). The challenge of international human resource management: Balancing the duality of strategy and practice. The International Journal of Human Resource Management, 16(4), 584-598.

5. Gorsline, K., Hawthorne, T., \& Ho, K. (1998).Moving competencies off the page and into people. The Competencies Case Book, HRD Press, Amherst, 297-334.

6. Grinold, R. C., \& Marshall, K. T. (1977). Manpower planning models. New York: North-Holland.

7. McDaniel, D. L. (1998).A competency model for human resources. The Competency Case Book", HRD Press, Amherst, 121 157.

8. Schuler, R. S. (2001). Human resource issues and activities in international joint ventures. International Journal of Human Resource Management, 12(1), 1-52.

9. Sternberger, W. B. (2003). The changing role of the human resource profession: The transformation of the HR function from an administrative, transactional orientation into a strategic business partnership.

10. Ulrich, D., Brockbank, W., Johnson, D., \& Younger, J. (2010). Human resource competencies: Rising to meet the business challenge. The RBL White Paper Series.

11. Klink, M. V. D., \& Boon, J. (2002).The investigation of competencies within professional domains. Human Resource Development International, 5(4), 411-424. 